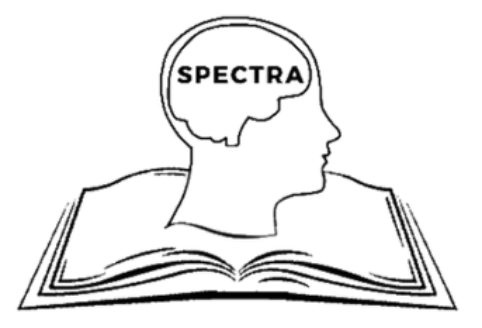

Spectra Undergraduate Research Journal

Volume 1, Issue 2

Office of Undergraduate Research

University of Nevada, Las Vegas

digitalscholarship.unlv.edu/spectra/

\begin{tabular}{|c|c|}
\hline & Category \\
\hline & Arts, Humanities, and Social Sciences $>$ Business $>$ Economics \\
\hline & Received \\
\hline & April 23, 2021 \\
\hline & Accepted \\
\hline & July 19,2021 \\
\hline & Published \\
\hline & August 13, 2021 \\
\hline & Article Title \\
\hline & The Future of the Live Entertainment Tax in Southern Nevada \\
\hline & Authors \\
\hline & Katie Gilbertson $(\mathrm{KG})^{1,2^{*}}$ \\
\hline & Author Affiliations \\
\hline & $\begin{array}{l}\text { 12Department of Economics, University of Nevada, Las Vegas, Las Vegas, NV, USA. } \\
\text { 2Brookings Mountain West, University of Nevada, Las Vegas, Las Vegas, NV, USA. }\end{array}$ \\
\hline & Corresponding Author \\
\hline & *Katie Gilbertson, katelin.gilbertson@unlv.edu \\
\hline & Author Contributions \\
\hline & $\begin{array}{l}\text { KG: Contributed conceptualization, data collection and analysis, original draft of manuscript, and } \\
\text { revisions to final draft. }\end{array}$ \\
\hline & Copyright \\
\hline & $\begin{array}{l}\text { (C) } \quad \text { Articles in Spectra are freely available under a Creative Commons Attribution } \\
\text { License (CC BY 4.0) which allows others to re-use the work without permission as } \\
\text { long as the work is properly cited. }\end{array}$ \\
\hline & ISSN \\
\hline & $2766-7227$ \\
\hline & Data Availability Statement \\
\hline & $\begin{array}{l}\text { The author of this article confirms that all research cited in this paper is publicly available without } \\
\text { restrictions. }\end{array}$ \\
\hline & Conflicts of Interest \\
\hline & The author declares that there are no conflicts of interest. \\
\hline & Ethical Considerations \\
\hline & $\begin{array}{l}\text { This project did not involve human or animal subjects. No IRB or IACUC approval was needed. Data } \\
\text { presented in this paper are all publicly available. }\end{array}$ \\
\hline & Funding \\
\hline & $\begin{array}{l}\text { The author is a part-time employee of Brookings Mountain West and The Lincy Institute. No } \\
\text { additional funding was provided for this research. }\end{array}$ \\
\hline & Recommended Citation \\
\hline & $\begin{array}{l}\text { Gilbertson, K. (2021). The future of the live entertainment tax in Southern Nevada. Spectra } \\
\text { Undergraduate Research Journal, } 1(2), 47-55 . \mathrm{https} \text { ://doi.org/10.9741/2766-7227.1009 }\end{array}$ \\
\hline
\end{tabular}




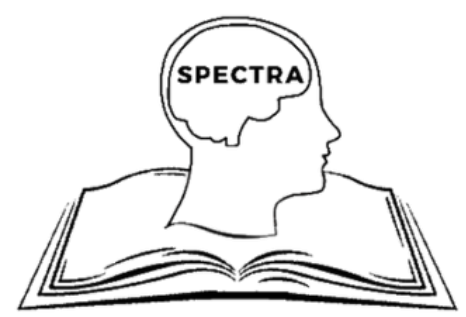

Spectra Undergraduate Research Journal

Volume 1, Issue 2

Office of Undergraduate Research

University of Nevada, Las Vegas

digitalscholarship.unlv.edu/spectra/

\title{
The Future of the Live Entertainment Tax in Southern Nevada
}

Katie Gilbertson ${ }^{1,2}$

Author Affiliations:

${ }^{1}$ Department of Economics, University of Nevada, Las Vegas, Las Vegas, NV, USA.

${ }^{2}$ Brookings Mountain West, University of Nevada, Las Vegas, Las Vegas, NV, USA.

\begin{abstract}
The Live Entertainment Tax (LET) in Nevada generated nearly one billion dollars during the 2019-2020 fiscal year. LET revenue all goes to the State General Fund, even though 97 percent of LET revenue is generated in Clark County. Nevada is experiencing an economic crisis, particularly in the tourism industry. Solutions from various fields suggest the best way to boost the local economy is to reinvest revenue in its original county. One policy solution Nevada policymakers should consider is to carve out a percentage of revenue generated by the LET to return directly back to Clark County to revitalize tourism.
\end{abstract}

Keywords: Live entertainment tax, live entertainment, taxation, fiscal policy

\section{Taxing the Tourism Industry}

When people think of Nevada, they think of an exciting vacation to Las Vegas. Tourism is a staple industry for the state economy; in 2019 the Southern Nevada tourism industry generated approximately “\$63.6 billion, equating to 52.0 percent of the region's total gross product" (Las Vegas Convention and Visitor's Authority, 2020, p. 6). Most of this revenue contributes towards funding state operations through taxes. Capitalizing on Las Vegas tourism assets is an essential component of the overall state budget and General Fund.

One essential component to the Las Vegas hospitality industry is live entertainment. The Live Entertainment Tax (LET) in Nevada is a nine percent admissions charge on any facility that provides recreational services or any similar purpose event with a minimum occupancy of 200, where both the entertainers and audience must be in physical attendance (Nevada Department of Taxation, n.d). The Live Entertainment Tax is a small contributor (2.8 percent) to the State General Fund (The Guinn Center, n.d.). The following sections will provide a breakdown of the LET relative to the state's fiscal policy along with a tourism tax comparison to another entertainment capital in the nation, Florida.

Historical Importance of the LET: There is a longstanding history behind the Live Entertainment Tax in Nevada. Primarily, Nevada legalized gaming in 1931 , as an attempt to pull the state out of the Great Depression (Nevada Legalizes Gambling, n.d.). As casinos quickly became popular, the demand for live entertainment attracted headlining stars to perform in Las Vegas. The federal government subsequently imposed two 10 percent taxes on the lucrative industry: the Admissions Tax and the Cabaret Tax. The Cabaret Tax applied to any lounge or showroom in a casino while the Admissions Tax covered all other casino amenities and recreation (Roberts, 2015). As Las Vegas began to boom in the 1960s, the state wanted to capitalize on their competitive advantage, so the Casino Entertainment Tax was enacted in 1965 
(Roberts, 2015). It required that casinos pay 10 percent of entertainment revenues to the state, however it only applied to entertainment offered at casinos ( $\underline{\text { Roberts, }}$ $\underline{2015)}$.

The Casino Entertainment Tax was enforced for 38 years until its termination in 2003. A special session of the Nevada Legislature created the Live Entertainment Tax (LET), which expanded the tax to live entertainment offered at any type of facility, not just casinos (Roberts, 2015). This new tax established that the Gaming Control Board and Department of Taxation were to have duel administrative control. The main difference between the Casino Entertainment Tax and the new Live Entertainment Tax was that for events under 7,500 people, the tax rate was 10 percent but for events exceeding 7,500 people, the rate was reduced to five percent (Roberts, 2015).

Twelve years later in 2015, the LET was revised. The updated LET is a tax rate of nine percent on events with 200 or more people, basing the tax on a minimum occupancy rather than the prior maximum occupancy rule (Nevada Department of Taxation, n.d.). This current occupancy requirement allows more tax revenue to be collected from the increasing amount of large-scale entertainment shows.

The long history of an entertainment tax in Nevada demonstrates its importance to supporting the state government. Beginning with the Casino Entertainment Tax in 1965, this tax has become imperative for the state budget. However, the changes in the legislation throughout the years also displays there is a need to adapt the tax to everchanging circumstances in the state. As Las Vegas continues to grow with new hotels and casinos, major league sport teams, and renovations to the convention center, it paints a perfect picture for yet another revision to the LET.

The Not-So-General Live Entertainment Tax: The General Fund is a collection of taxes paid by each county and then distributed back out to each county through state government departments. Sales tax is the main contributor to the General Fund at 30.2 percent, while the LET contributes to 2.8 percent of the total statewide fund (The Guinn Center, n.d.). The LET makes up a small share of the overall General Fund. According to the Guinn Center, the General Fund is primarily dispersed to the Department of Education and Department of Health and Human Services in each county (The Guinn Center, n.d. p. 1). While these are important departments, the profits generated from the LET are not being used for anything tourism related.

The Live Entertainment Tax is defined by the Nevada Revised Statue (NRS) Chapter 368A. The legislation explains that live entertainment is "any activity provided for pleasure, enjoyment, recreation, relaxation, diversion or other similar purpose by a person or persons who are physically present when providing that activity to a patron or group of patrons who are physically present," (Tax on Live Entertainment, 2015). Examples of this would include live music, theater shows, or circus acts. Distinguishing what is considered live entertainment under the NRS has always been a grey area. Some Nevada lawmakers have called for a simpler definition to avoid confusion (Walczak, 2015).

Under NRS 368A.220, all reports and payments generated by the LET will be credited to the State General Fund. Per the legislation, "Filings of reports and payment of tax; deposit of amounts received in State General Fund," which demonstrates LET collections are sent to the State General Fund (Tax on Live Entertainment, 2015). In addition, NRS 368A.220 explains that $\$ 150,000$ of the LET will go toward the Nevada Arts Council each year (Tax on Live Entertainment, 2015). There are two agencies responsible for oversight and administration of the LET: the Gaming Control Board administers events in licensed gaming establishments and the Department of Taxation administers events in non-gaming establishments.

A majority of LET revenue is generated in Southern Nevada, yet all that money gets funneled into the State General Fund. In 2017, 97 percent of revenue generated by the LET came from Clark County; this breaks down to $\$ 125$ million contribution from Clark County and \$3.8 million from the remainder of the state (Las Vegas Convention and Visitor's Authority, 2018) This 2017 report produced by the Las Vegas Convention and Visitors Authority is the most recent data that reveals the impact tourism in Clark County has on the entire state. Despite generating 97 percent of LET revenue in Clark County, none of it is specifically retained in the county where it originated. NRS 368A explains that all of the revenue generated from the LET 
funnels to the State General Fund or the Nevada Arts Council; Clark County does not retain any of this revenue, even though 97 percent originates in Clark County. Figure 1 depicts the LET revenue flow in
Nevada. A nine percent admissions charge is collected at events, 97 percent of revenue comes from Clark County but goes to the State General Fund, and each county receives a portion of the State General Fund.

\section{Figure 1.}

\section{Live entertainment tax revenue flow in Nevada}

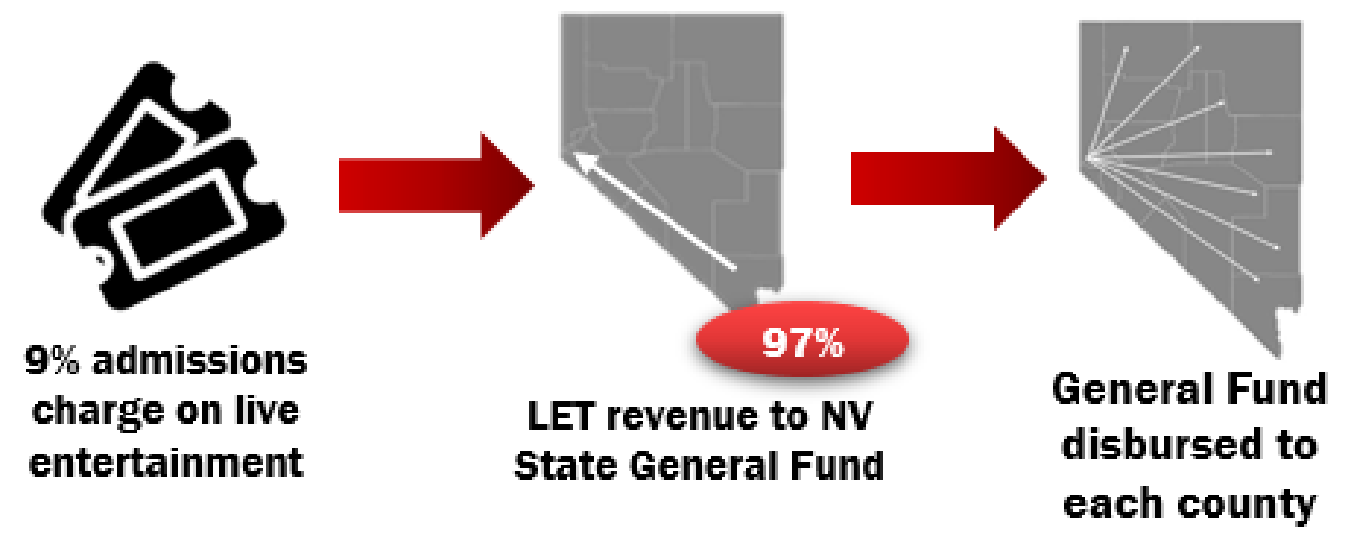

Note. Adapted from The Industry's Contribution to Major Public Revenues, by Las Vegas Convention and Visitors Authority, 2018

(http://res.cloudinary.com/simpleview/image/upload/v1534980634/clients/lasvegas/EIS_Fiscal_Impacts_May_2 018_FINAL_25916e2e-e38c-47b2-af51-1a7d09bd4af3.pdf). In the public domain.

The State of Play in Las Vegas: Live entertainment plays an integral role in the future of Las Vegas. An article by The Wall Street Journal reports "Three decades ago, Las Vegas Strip casino resorts made about $58 \%$ of their revenue from gambling, while just $8 \%$ came from entertainment and retail... In 2019, it said, casinos generated less than $35 \%$ of revenue from gambling, while $13 \%$ came directly from entertainment and retail," a five percent jump in tourist spending to entertainment (Sayre, 2020). Moreover, the Guinn Center, a bipartisan research and policy analysis center, found that LET revenue was projected to increase overall 12.1 percent from the 2018-2019 biennium to the 2020-2021 biennium (The Guinn Center, n.d., p. 7). The gaming venues contribution to LET was expected to decrease -0.5 percent while the non-gaming revenue was projected to increase 12.6 percent, in only four years (The Guinn Center, n.d., p. 7). While business closures and strict gathering restrictions have offset this prediction, it is encouraging that live entertainment was heading the right direction before the COVID-19 pandemic.
The number of celebrities establishing Las Vegas residencies is everchanging, along with new venues and casinos that continue to grow the tourism economy. New properties such as Circa in Downtown Las Vegas and Resorts World on the Las Vegas Strip demonstrate the demand for new venues and experiences in Las Vegas. The Madison Square Garden Sphere is another new arena set to open in 2023. Moreover, Clark County is rapidly growing. Population estimates from the Center for Business and Economic Research at UNLV delineate Clark County is expected to grow by 15 percent in the short span of 15 years from 2020 to 2035 (Center for Business and Economic Research, 2019, p. 22). Emerging from a shambled service-sector economy, Las Vegas has the potential to distinguish itself as the leading tourist destination in the world, if it plays its cards right.

\section{Recommendations for Policy}

There are existing taxation strategies that Nevada should consider in order to better utilize LET revenue. First, Florida tourism taxes are imposed at the county level, and each county retains 100 percent of the 
revenue for a particular facet of the tourism industry. Second, the Nevada mining tax is an example of a carve-out tax in the state, where the county and state spilt the revenue generated from that industry.

The state of Nevada and Clark County should consider creating a carve-out tax for the LET. This solution would allow for a reinvestment in leisure and hospitality in Las Vegas and provide the city with necessary resources to reinvest in the state's main economic industry. Dr. Robert E. Lang, former Executive Director at The Lincy Institute and Brookings Mountain West, emphasized that though initially the shock to the statewide General Fund may be debilitating, the long-term return on investment with increased tourism to Las Vegas would benefit the entire state.

The Standard Set by Florida: One of Nevada's main competitors in the hospitality industry is Florida. There is much to learn from Florida, home to destinations such as Miami Beach and Walt Disney World. Notably, their taxation policies for the tourism industry allows local option taxes for each county, where the revenue generated goes specifically toward tourism development (Florida Department of Revenue, n.d.). Examples of these taxes include professional sports franchise facility tax, transient rental taxes, tourism impact tax, convention development tax, and municipal resort tax (Florida Department of Revenue, n.d.).

\section{Figure 2.}

\section{Tourism carve-out tax revenue flowchart}

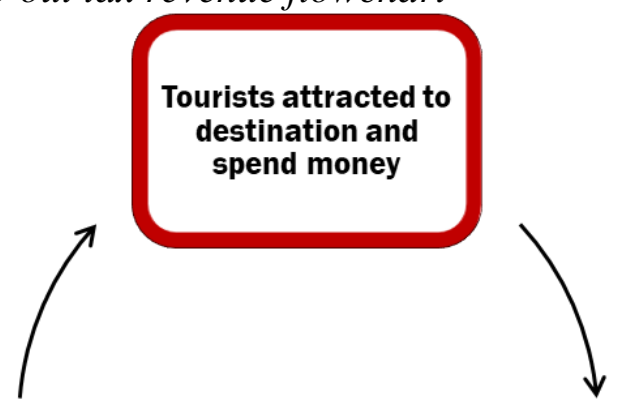

The three largest counties in the state (MiamiDade, Broward, and Palm Beach) have the highest amount of tourism related taxes possible, which is six percent (Florida Association of Counties, n.d.). Each of these counties retains 100 percent of the revenue generated from the taxes they wish to employ. In other words, the tax revenue is "carved-out" for each county, separate from being paid to the state. Profits generated by each tax have a specific function. For instance, convention development tax revenues "may be used for capital construction of convention center and other tourist-related facilities as well as tourism promotion" (Florida Department of Revenue, n.d.). Money generated from the county's primary economic driver is reinvested into tourism operations.

There is reason to believe Florida's tourism carve-out tax works. Forbes named Florida the top U.S. Travel Destination in October of 2020 (Whitmore, 2020). Explanations for this acclaimed title include the numerous theme parks and beaches, both of which are under the jurisdiction of tourism development taxes (Florida Department of Revenue, n.d.). Florida serves as a standard for states with a high concentration in leisure and hospitality sectors because the profits generated by the industry have lasting impacts. Figure 2 illustrates a revenue flow from a tourism carve-out tax. This effective model demonstrates an ideal use for the Live Entertainment Tax in Nevada.
Revenue from visitor spending retained in county for tourism development 
The Nevada Mining Tax: Notably, a carve-out tax structure already exists within the state, serving as a potential model for the LET. Generally, the mining tax revenue is split fifty-fifty to the state and local county governments (Bahouth, 2020). An article from The Sierra Nevada Ally reports that Humboldt County's share of the mining tax is its single largest source of revenue, highlighting the importance a carve-out tax can have in a county budget (Bahouth, 2020).

Amidst substantial budget deficits, the state considered increasing the tax on the mining industry during the 31st Special Session in July of 2020. Assembly Joint Resolution (AJR) 1 proposed an increase from five percent on net profits to 7.75 percent tax on gross profits; Assembly Joint Resolution 2 proposed a 12 percent tax on net profits (Gray, 2020). Both measures will have to be voted on during the 2022 election in order to take effect. Either scenario shows the importance of a carve-out tax to both the state and local rural governments in a time where funding is desperately needed.

Live Entertainment Carve-Out Tax: The LET is an opportunity for Clark County to capitalize on the revenue that its county overwhelmingly generates a majority of. A carve-out tax would allocate the revenue generated by a tax back to the county where it was generated, rather than pooling it to the statewide General Fund. For Clark County, this would bring a considerable amount of initial revenue along with a dramatic lasting effect.

For example, an argument for a LET carve-out tax was presented during the proposals to create Allegiant Stadium. The idea was for entertainment tax revenue to be used specifically for entertainment venues, such as the new stadium (Lang, 2016). However, a LET carve-out tax was not implemented to fund Allegiant Stadium, but rather an additional hotel room tax imposed on tourists (Velotta, 2020). A 2005 study conducted by scholars at Nottingham University found that directly imposing taxes on tourists leads to counterintuitive outcomes, such as decreased GDP and increased inflation (Gooroochurn and Sinclair, 2005). Alternatively, Clark County could have utilized an existent revenue stream, the LET, to pay the public share cost of Allegiant Stadium. The estimated annual economic impact of the Las Vegas Stadium is $\$ 620$ million (Southern Nevada Tourism Infrastructure
Committee, n.d., p. 1). Yet if LET revenue were used instead of shifting the cost burden to tourists through an additional room tax increase, the economic output of the stadium could potentially be greater. The stadium illustrates one example of the potential for LET revenue to be reinvested in the Las Vegas entertainment industry.

The direct financial numbers generated from the LET are only a fraction of the story; tourism supports the Las Vegas community through direct, indirect, and induced impacts. Direct impact could bring approximately $\$ 91$ million to Clark County, following the 2019-2020 revenue stream (Clark County Department of Finance, n.d.). Indirect and induced impacts are the ripple effects of a carve-out live entertainment tax in Clark County: indirect is a supply chain analysis while induced is the demand for local employees, both directly and indirectly ( $\mathrm{Lim}$, 2020, p. 5). Though the exact figures for the indirect and induced impacts of the LET are unknown, they will multiply the original investment brought to Clark County (Lim, 2020, p. 5). LET revenue could create an unpredictable number of opportunities for Southern Nevada.

Carve-out Controversies: A carved-out live entertainment tax would shift the revenue from the General Fund to Clark County, however statewide concern is apparent. As previously mentioned, the state budget was significantly reduced during 2020 due to the leisure and hospitality shutdowns during the middle of the year. Counties across the state rely on the General Fund for healthcare and public education funding. Reallocating the LET revenue from the State General Fund to Clark County would strip the other 16 counties of General Fund aid that is vital to their communities. In a conversation on September 10, 2020, with Dr. Lang, he explained the political tension between Northern and Southern Nevada regarding the allocation of LET revenue. Lang clarified that representatives from Reno and Carson City want to retain their respective county shares of the LET and preserve the status quo, meanwhile Las Vegas representatives want to keep the revenue in their county where it is mainly created.

Aside from political implications the carve-out tax structure is an opportunity to target revenue back to its respective industry in order to reinvest in that sector. 
It would be odd for Clark County to receive money from the mining tax, just as it is odd for Lander County, a rural mining county, to receive money from live entertainment. Counties should receive money respective to their leading industry. For the hospitality industry, this method has worked well for Florida. Those counties impose a six percent tourism tax and retain all of the revenue; even if Nevada counties receive half of the nine percent LET revenue it would be better than not directly receiving any direct funding. A live entertainment carve-out tax would place Nevada in the ideal Florida scenario, where revenue continuously cycles to promote the industry.

\section{Policy Implementation and Evaluation}

Policymakers should consider two key reasons for implementing a live entertainment carve-out tax. First, a carve-out tax structure already exists within Nevada for mining taxes and in Florida for tourism development taxes. Second, generating more money in the leisure and hospitality sector will lead to a better overall state economy. The carve-out structure serves as a way to direct LET revenue to an avenue where the money can be utilized for its intended purpose.

Moreover, many tourism-related taxes already distribute out to the entire state. Sales tax, bed tax, and rental car tax are just a few examples of taxes that can be augmented with a better tourism industry-which Figure 3.

Potential live entertainment carve-out revenue

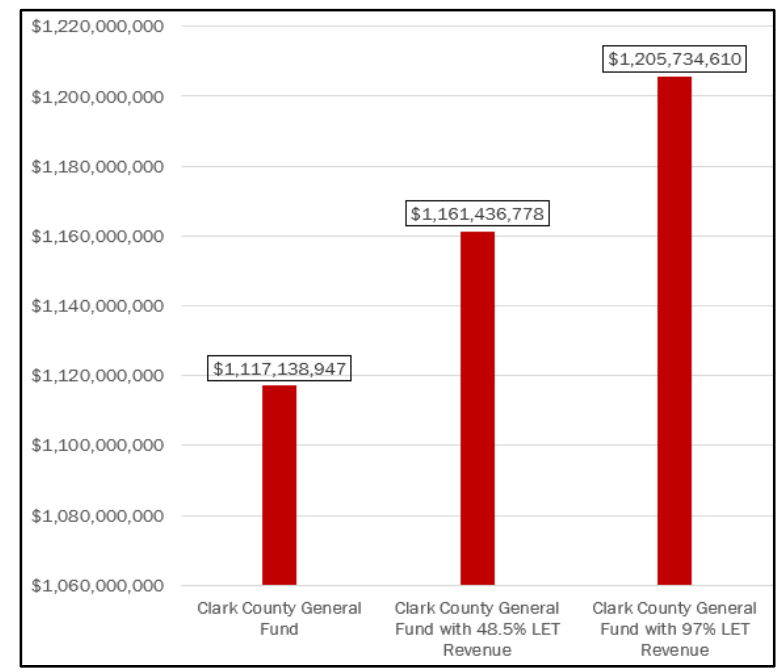

Note. Adapted from the Clark County General Fund FY 20, by Clark Country Department of Finance, n.d. (https://files.clarkcountynv.gov/clarknv/Finance/Financial\%20Reporting/Budget/FY\%202019-

20\%20Final/General\%20Fund\%20FY\%2020\%20Final.pdf? $\mathrm{t}=1602110957838 \& \mathrm{t}=1602110957838$ ). In the public domain. could be accomplished by concentrating LET revenue in Clark County. Direct, indirect, and induced impacts of increasing visitation will provide a better comprehensive payoff for Nevada. In the midst of economic recession, legislators should be looking for new ways to generate additional income. A Brookings Institution report after the Great Recession found that a decline in the General Fund substantially contributes to a decline in overall state economic health (Gordon, 2011). Given Nevada's current economic situation, legislators should explore new options for financial recovery, mainly a live entertainment carve-out tax.

Economic Projections and Proposals: Two scenarios can be evaluated to measure the impact of a LET carveout for Clark County, as depicted in Figure 3. The first would be to follow the Florida model, where the county retains 100 percent of their local option tax. In Clark County, that would mean the county would receive 97.0 percent of the LET revenue and add \$88.6 million dollars to the Clark County General Fund, totaling at $\$ 1.2$ billion. The second scenario follows the Nevada Mining Tax where the state and county evenly split the tax revenues. In this instance, Clark County would receive 48.5 percent of the LET and add $\$ 44.3$ million to their General Fund. Scenario two would increase the Clark County General Fund to $\$ 1.16$ billion. The figure below illustrates these projections using data from the 2019-2020 budgets. 
The Tourism Development Budget: How should Clark County use this potential new revenue source? There are already existing solutions for how to subsidize the tourism industry. The Tourism Development Budget for Nevada is designed to encourage tourism and promote overnight visitations (Budget 1522-Tourism, 2017). Ways to execute this goal include "Robust research program measuring visitation...traditional and digital advertising....conferences designed to enhance business opportunities for Nevada's tourism industry," all of which can be accomplished in Clark County with potential LET carved-out revenue (Budget 1522-Tourism, 2017).

The LET can supplement the tourism economy in ways like Florida. In those counties, tourism-specific revenue is reinvested into its respective industry through improving infrastructure and advertising. In Nevada's case, the LET would go toward enhancing the Las Vegas vacation experience. Whether it be through enhanced cleaning protocols to make visitors feel safe or incentivizing conventions to return to Las Vegas, this carved-out LET revenue would be especially helpful during an economic recession.

Conclusion and Considerations for Further Analysis: Evaluating a live entertainment carve-out tax will take some time. This change would not bring dramatic results right away- rather it would depend on the longterm health of the tourism economy in Las Vegas. Once that tax revenue is collected, it will have to be spent on creating a more enjoyable guest experience for those traveling to Las Vegas. If funneling more money into the Southern Nevada tourism mediates projected losses to the State General Fund, then a live entertainment carve-out tax will prove its effectiveness. If the General Fund suffers and loses more money than projected due to the loss of LET revenue, then the carve-out should be eliminated.

This report serves as a preliminary analysis on the potential of a LET carve-out tax. There is a significant gap in the state fiscal policy on this topic. There is not much existing data available on the impact of the LET to Nevada, especially in academic research. In order to effectively use entertainment taxes to bolster and strengthen the growing Las Vegas entertainment industry, Nevada policymakers will need to reassess how LET revenue could be utilized.
This report is a benchmark analysis of the potential for Clark County to receive a proportionate share of LET revenue.

Further analysis should be conducted on this topic. This could be accomplished through analyses of the LET's contributions to the State General Fund and its proposed impact through a Clark County carve-out tax. Economists should weigh the costs and benefits of a carve-out tax. With more data, policymakers can decide which type of carve-out tax to implement, either the Nevada Mining Tax model or Florida Tax model, or a new type of model. The LET carve-out tax would need to be monitored in the long-term to measure its effects on the overall economy. This discussion should promote further academic research on a LET carve-out tax and Nevada fiscal policy in general. The state has a significant opportunity to reinvest in its main competitive advantage, and this report serves a foundational document for a LET carve-out tax.

\section{Discussion and Policy Implications}

Limitations exist within the scope of this analysis. First, available General Fund budgets do not provide county-level revenues and expenditures reports; this information is only available for the state. Second, live entertainment has taken a drastic hit in the midst of COVID-19. Closures of entertainment venues and strict social distancing limits have inhibited Las Vegas live entertainment in 2020. Until visitors and performers feel safe to return, there will be drastic impacts on LET revenue.

Lack of Budget Transparency: This brief provides an approximate estimate for economic proposals. However, it is difficult to project accurate fiscal implications with the lack of available data. For instance, the aggregate amount of LET revenue is available from the Detailed Unrestricted Revenues report but each county's contribution is not listed. The statistic that 97 percent of LET revenue is generated in Clark County was provided by the Las Vegas Convention and Visitors Authority in their Industry's Contribution to Major Public Revenues report from 2018. This is the most recent statistic. Moreover, there is no data available as to how taxes that pool into the General Fund are distributed amongst the counties. Rather, the counties receive a certain amount of the 
"General Fund," so there is no way to know how much LET revenue is being distributed to each county.

Budget transparency would provide much more accurate data for this report. Necessary information includes the amount of LET revenue each county generated and how much LET revenue each county received through the General Fund. With more descriptive financial reports, it would create a better projection for the impacts a carve-out LET would potentially have. The findings in this policy brief encourage more economic data to be discovered on the topic.

Work Safe, Play Safe: To strive ahead, Clark County should find new ways to make leisure and hospitality safe. Guests will not return in their similar volumes until they feel comfortable in a casino atmosphere. Likewise, employees in the industry will not feel safe working near people unless they are adequately supplied with protective equipment. According to experts at the Brookings Institution, the first step in a framework for "COVID-19 response, relief, and recovery in the leisure and hospitality sector" is supporting workers (Loh, 2020). This study identified Las Vegas with the largest workforce exposed to incoming visitors. Therefore, it is imperative that these workers receive adequate safety equipment when returning to work. If Americans see the number of COVID-19 cases continue to climb in Southern Nevada they will not want to visit Las Vegas. LET revenue could supplement the effort to make the Las Vegas Strip a cleaner and safer destination for employees and visitors alike.

\section{Acknowledgements}

The author thanks both the Director of Strategic Development at Brookings Mountain West and The Lincy Institute, Dr. Caitlin J. Saladino, and UNLV Director of Brookings Mountain West, William E. Brown, Jr., for their continued support and assistance throughout the research process. The author also appreciates the work of former Executive Director of The Lincy Institute and Brookings Mountain West, Dr. Robert E. Lang. Dr. Lang initially illuminated the possibilities of restructuring the LET; the author is especially grateful for his guidance on this report and overall instrumental contributions to public policy in
Southern Nevada. Without their contributions, this research endeavor would not have been possible.

\section{References}

Bahouth, B. (2020, August 9). Rural Nevada counties, mining industry fret proposed changes to mining taxation. The Sierra Nevada Ally. https://sierranevadaally.org/2020/08/08/ruralnevada-counties-mining-industry-fretproposed-changes-to-mining-taxation/

Budget 1522-Tourism-Tourism Development Fund Overview. (2017). https://www.leg.state.nv.us/App/NELIS/REL/ 79th2017/Budget/5585/Overview

Center for Business and Economic Research. (2019). 2019-2060 population forecasts. https://files.clarkcountynv.gov/clarknv/Planni ng/Demographics/2019\%20CBER\%20Populat ion\%20Forecasts.pdf

Clark Country Department of Finance. (n.d.). Clark County general fund FY 20 https://files.clarkcountynv.gov/clarknv/Financ e/Financial\%20Reporting/Budget/FY\%20201 9-

20\%20Final/General\%20Fund\%20FY\%2020 $\% 20$ Final.pdf?t=1602110957838\&t $=1602110$ 957838

Florida Association of Counties. (n.d.). County population and general information. https://www.fl-counties.com/countypopulation-and-general-information

Florida Department of Revenue. (n.d.). Local tax options.

https://floridarevenue.com/taxes/taxesfees/pag es/local_option.aspx\#

Gray, T. (2020, September 4). Nevada mining: important then - critical now. Elko Daily Free Press.

https://elkodaily.com/mining/nevada-miningimportant-then-critical-now/article efa9d3999a86-5837-89ca-f27c2900b8c0.html

Gooroochurn, N., \& Sinclair, M. T. (2005).

Economics of tourism taxation: Evidence from Mauritius. Annals of Tourism Research, 32(2), 478-498.

Gordon, T. (2011). State budgets in recession and 
recovery. Brookings Institution.

https://www.brookings.edu/research/statebudgets-in-recession-and-recovery/

Lang, R. (2016). Five Key Infrastructure investments to restart Las Vegas job growth [PowerPoint slides]. University of Nevada, Las Vegas. http://sntic.org/meeting/08/session2/jessup/SN TIC\%20Talk\%20March\%202016.pdf

Las Vegas Convention and Visitors Authority. (2018). The fiscal impact of Southern Nevada's tourism: The industry's contribution to major public [Economic Impact Series Brief], 1-12. http://res.cloudinary.com/simpleview/image/u $\mathrm{pload} / \mathrm{v} 1534980634 / \mathrm{clients} /$ lasvegas/EIS_Fisc al_Impacts_May_2018_FINAL_25916e2ee38c-47b2-af51-1a7d09bd4af3.pdf

Las Vegas Convention and Visitors Authority. (2020). Economic impact of Southern Nevada's tourism industry and convention sector [Economic Impact Series Brief], 1-20. https://res.cloudinary.com/simpleview/image/ upload/v1598283376/clients/lasvegas/EIS_Ec onomic_Impacts_Apr_2020_07b2a914-b1f24006-bff3-d275391ed850.pdf

Lim, J. (2020). The economic impact of COVID-19: Rebuilding the Las Vegas economy. The Lincy Institute [Policy Brief], 1-17. https://digitalscholarship.unlv.edu/lincy_polic ybriefs_reports $/ 1$

Loh, T. H., Goger, A., \& Liu, S. (2020, August 20). 'Back to work in the flames': The hospitality sector in a pandemic. Brookings Institution. https://www.brookings.edu/blog/theavenue/2020/08/20/back-to-work-in-theflames-the-hospitality-sector-in-a-pandemicl

Nevada Department of Taxation. (n.d.). Live entertainment tax \& FAQ's. https://tax.nv.gov/FAQs/Live_Entertainment_ Tax_FAQ\%E2\%80\%99s/

Nevada Legalizes Gambling. (n.d.). History. https://www.history.com/this-day-inhistory/nevada-legalizes-gambling

Roberts, J. (2015, May). A primer on the live entertainment tax. Nevada Lawyer Magazine, 23(5), 22-24.

http://www.nvbar.org/wpcontent/uploads/NevadaLawyer_May2015_En tertainmentTax.pdf

Sayre, K. (2020, Oct 26). Return of big Las Vegas Shows proves to be a high-wire act. The Wall Street Journal. https://www.wsj.com/articles/return-of-biglas-vegas-shows-proves-to-be-a-high-wire-act11603718135

Southern Nevada Tourism Infrastructure Committee. (n.d.). Impact summary: Las Vegas stadium development and operations. http://sntic.org/meeting/17/staff/SNTIC\%20St adium\%20Economic\%20Impact\%20Brief.pdf

Tax on Live Entertainment, NRS Chapter 368A.220 (2015). https://www.leg.state.nv.us/nrs/nrs368a.html

The Guinn Center. (n.d.). Nevada budget overview 2019-2021, 1-36. https://guinncenter.org/wpcontent/uploads/2019/02/Guinn-CenterBudget-2019-2021.pdf

Velotta, R.N. (2020, August 27). Here's a look at the finances behind \$1.9B Allegiant Stadium. Las Vegas Review-Journal.

https://www.reviewjournal.com/business/stadi um/heres-a-look-at-the-finances-behind-1-9ballegiant-stadium-2106708/

Walczak, J. (2015, April 3). Legislators take on the taxing logic of Nevada's live entertainment tax. Tax Foundation. https://taxfoundation.org/legislators-taketaxing-logic-nevada-s-live-entertainment-tax/

Whitmore, G. (2020, October 2). Where is the top travel destination in the U. S.? Forbes. https://www.forbes.com/sites/geoffwhitmore/2 020/10/22/where-is-the-top-travel-destinationin-the-us/ 